Meta

Journal des traducteurs

Translators' Journal

\title{
Foreignization in News Translation: Metaphors in Russian Translation on the News Translation Website InoSMI
}

\section{Piet Van Poucke et Alexandra Belikova}

Volume 61, numéro 2, août 2016

URI : https://id.erudit.org/iderudit/1037763ar

DOI : https://doi.org/10.7202/1037763ar

Aller au sommaire du numéro

Éditeur(s)

Les Presses de l’Université de Montréal

ISSN

0026-0452 (imprimé)

1492-1421 (numérique)

Découvrir la revue

Citer cet article

Van Poucke, P. \& Belikova, A. (2016). Foreignization in News Translation: Metaphors in Russian Translation on the News Translation Website InoSMI. Meta, 61(2), 346-368. https://doi.org/10.7202/1037763ar
Résumé de l'article

L'emploi métaphorique est récurrent dans les textes à caractère journalistique. Cet article étudie la façon dont les traductions russes de textes originaux traitent les expressions métaphoriques et vise à circonscrire les stratégies traductives utilisées. Dans une première étape, nous avons constitué un double corpus de soixante articles originaux en anglais, néerlandais ou finnois accompagnés de leur traduction russe. La comparaison des métaphores identifiées dans les textes sources avec leurs équivalents russes permet ensuite de déterminer dans quelle mesure certaines images acquièrent dans le texte cible un degré d'étrangeté absent dans le texte original. La dernière phase de l'enquête consiste en l'analyse des cas exotisants afin de préciser la motivation qui explique le recours à cette stratégie traductive. L'article montre comment, dans un certain nombre de contextes spécifiques, le procédé d'exotisation garde en effet la trace de points de vue occidentaux sur des sujets concernant la Russie, plus particulièrement lorsque les métaphores des textes sources font affleurer une interprétation critique de la société russe, de la structure de l'État ou de ses dirigeants.
Ce document est protégé par la loi sur le droit d'auteur. L'utilisation des services d’Érudit (y compris la reproduction) est assujettie à sa politique d'utilisation que vous pouvez consulter en ligne.

https://apropos.erudit.org/fr/usagers/politique-dutilisation/ 


\title{
Foreignization in News Translation: Metaphors in Russian Translation on the News Translation Website InoSMI
}

\author{
PIET VAN POUCKE \\ Universiteit Gent, Ghent, Belgium \\ Piet.VanPoucke@UGent.be
}

ALEXANDRA BELIKOVA

Aalto University, Espoo, Finland

alexandra.belikova@aalto.fi

\begin{abstract}
RÉSUMÉ
L'emploi métaphorique est récurrent dans les textes à caractère journalistique. Cet article étudie la façon dont les traductions russes de textes originaux traitent les expressions métaphoriques et vise à circonscrire les stratégies traductives utilisées. Dans une première étape, nous avons constitué un double corpus de soixante articles originaux en anglais, néerlandais ou finnois accompagnés de leur traduction russe. La comparaison des métaphores identifiées dans les textes sources avec leurs équivalents russes permet ensuite de déterminer dans quelle mesure certaines images acquièrent dans le texte cible un degré d'étrangeté absent dans le texte original. La dernière phase de l'enquête consiste en l'analyse des cas exotisants afin de préciser la motivation qui explique le recours à cette stratégie traductive. L'article montre comment, dans un certain nombre de contextes spécifiques, le procédé d'exotisation garde en effet la trace de points de vue occidentaux sur des sujets concernant la Russie, plus particulièrement lorsque les métaphores des textes sources font affleurer une interprétation critique de la société russe, de la structure de l'État ou de ses dirigeants.
\end{abstract}

\section{ABSTRACT}

Journalistic texts, as a rule, contain a considerable number of metaphorically used expressions. This paper investigates the handling of metaphors in Russian translations of journalistic texts in order to reveal the different translation strategies used by the translators. The research is conducted in three consecutive steps. First, we identify all metaphors in a twofold corpus of 60 original Dutch, English and Finnish newspaper articles on the one hand, and their corresponding 60 translations into Russian on the other. Secondly, we compare the use of metaphors in the translations with their source texts in order to establish the translation strategies and to determine to which extent the metaphorical expressions in the target texts display a higher degree of foreignness than those used in the source texts. Finally, we analyze the cases of foreignization in the target texts in order to find an explanation for the use of this translation strategy. The investigation shows how foreignization is adopted by the translators in a certain number of specific contexts, making the Western discourse on Russian subjects more visible to the reader, especially in these cases where the source text contains metaphors that suggest a critical interpretation of the Russian state, society or the leaders of the country.

\section{MOTS-CLÉS/KEYWORDS}

traduction journalistique, métaphore, russe, exotisation, InoSMI. news translation, metaphor, Russian, foreignization, InoSMI. 


\section{Introduction}

This paper aims to investigate how metaphorically used expressions are translated from Dutch, English and Finnish into Russian. Since metaphors shape an important part of everyday life and are constantly present in our conscience, thought processes and culture, their handling in translation is one of the major translation problems to be studied. Different cultures may, on the one hand, share common images and ways of thinking, especially when they are closely related to each other by certain historical or cultural means but, on the other hand, there are also linguistic and cultural features that are so specific to a particular discourse, that they constitute a major translation problem.

Obviously, several factors can influence the translation of metaphors in news translation. First, we have the possibility of influence through the relative prestige of different languages and cultures. The current prestige of English as a central language for global communication could very well determine the choice of translation strategies in that the translation tends to borrow more words, expressions and images (including metaphors) from this lingua franca than from a more peripheral language such as Dutch or Finnish.

Secondly, the relative closeness of languages usually includes a certain number of shared features (again including metaphors) that can be translated more easily between those particular languages than between two more distantly related languages or cultures. In our case we are dealing with a comparison of discourse in two Germanic and one Finno-Ugrian languages compared with the translations into a Slavic language, which means no real linguistic connection is present. Still, Finland and Russia partly share common historic and geographic features that might influence the presence of common metaphors in those two languages.

Thirdly, the choice of translation strategy can also be influenced by the content of the discourse. Because the Dutch, English and Finnish articles share a common Western, objectively critical point of view, in particular towards Russia (and even more towards the predecessor of this state, the Soviet Union), some metaphorical images could be unwelcome to the Russian audience, which could become a reason to alter the image from the source text (ST) in the target text (TT).

Our hypothesis is that translators will resort to different translation tactics depending on the relative prestige the source language (SL) holds in a global perspective, and that these different tactics will lead to a differentiated approach to metaphor translation. A possible reinforcing factor in this process is the large number of texts that are translated on a daily basis from English, compared to less central languages like Dutch and Finnish, which inevitably leads to a stronger familiarity of Russian translators with Anglophone metaphors and, accordingly, with the idiomatic equivalents in their target language (TL).

\section{Metaphors and their identification in discourse}

\subsection{Metaphors}

Translation scholars have studied the translatability and, more specifically, the untranslatability of particular SL utterings for centuries. One of those seemingly untranslatable elements in discourse is metaphor. Since Lakoff and Johnson (1980) 
introduced the notion of conceptual metaphor in cognitive linguistics, metaphorical expressions are no longer seen as a pure matter of language and as a decorative element only, but also, and more importantly, as a matter of thought, a fundamental element in our thinking, that helps us understand one domain of experience (usually an abstract domain) in terms of another (usually more concrete) domain. Lakoff and Johnson (1980: 159) even consider metaphors to be "among our principal vehicles for understanding," that "play a central role in the construction of social and political reality." If we follow this line of thought, then we should consider metaphor as a central element in our perception of reality, which reflects our culture and is therefore a crucial feature in cross-cultural communication, of which translation is a major form of expression.

In this paper we examine the definition used by Dickins (2005: 228), who sees metaphor as "a figure of speech in which a word or phrase is used in a non-basic sense, this non-basic sense suggesting a likeness or analogy [...] with another more basic sense of the same word or phrase." Consequently, we not only focus on the obvious and highly marked appearances of metaphor in discourse, but we broaden the concept to all appearances of non-direct language, even in cases where not every reader is necessarily aware of the use of metaphorical language. A first problem to solve in this connection is the definition of a procedure to identify metaphor in discourse.

\subsection{Metaphor identification}

Traditionally, metaphors have been searched for in discourse more or less manually, which means that only obvious cases of metaphorically used expressions were taken into account and were studied for their aesthetic, mostly surprising effect on the reader. This method of selecting only the intended cases of metaphorical word use in discourse, however, presents a few difficulties.

First of all, without being able to look into the author's mind, we can never really know which metaphorical image was used with a specific goal by an author and therefore the identification of metaphors depends mainly on the reader's familiarity with the imagery in a certain language. Moreover, learned readers with a satisfactory level of knowledge of the language used will always recognize more metaphors than others, which turns metaphor identification into a mere subjective and non-scholarly activity.

Taking this specific problem into account, the Pragglejaz Group (2007) developed their Metaphor Identification Procedure (MIP), which was later improved by Steen, Dorst, et al. (2010) into MIPVU ${ }^{1}$. According to MIP (Pragglejaz Group 2007: 3), a text or discourse has to be cut up into lexical units first, and their meaning has to be established in context. Whenever a particular "lexical unit has a more basic current - contemporary meaning in other contexts than the given context" and "the contextual meaning contrasts with the basic meaning but can be understood in comparison with it," the lexical unit is considered to be metaphorical. This method is highly objective but also turns out to be very labor-intensive, since it involves the extensive use of dictionaries in order to establish the basic meaning of linguistic expressions in a text.

Considering the extended scope of the case study in our paper and the complexity of MIP (and the improved version of MIPVU), we decided to adapt this identification 
procedure slightly to suit our specific needs. A first restriction involves the exclusion of cases of personification in our corpus. Strictly speaking, personification also includes the use of non-basic meaning in discourse and could be selected through MIP(VU). However, personification is left out of consideration because of the highly asymmetrical use of this feature in different languages, for instance when comparing English to Russian. It is "a form of ontological metaphor," in which "human qualities are given to nonhuman entities," which is "common in literature, but it also abounds in everyday discourse” (Kövecses 2010: 39). As Barhudarov (1975: 201-202) correctly points out, personification is encountered much more in English than in Russian and should not be translated literally. Whenever they are translated we are normally dealing with highly conventional personifications that are equally used in the languages involved in this study and therefore do not confront the translator with any particular translation difficulty. A typical example of personification, present in texts of the four languages in this paper, are "the Soviet system collapsed" $\left(\mathrm{OE} 1^{2}\right)$ and "the Kremlin will be hoping" (OE7). These kinds of images are so universally used that they are of no real interest for the investigation of foreignizing tendencies in translation.

A second restriction on MIP(VU) includes the limitation of potential metaphorical expressions to the major word-classes (nouns, verbs and adjectives), excluding adverbs and prepositions, since "adverbial and prepositional V-terms ${ }^{3}$ are generally less recognizable as metaphors and less forceful than verbal and adjectival V-terms," which "in turn, are less forceful than noun-based ones" (Goatly 1997/2011: 81).

Even with these restrictions the case study in this paper demonstrates how the use of MIP(VU) provides research results with a relatively high percentage of metaphors, due to the fact that all nouns, verbs and adjectives in our case study that are used in a non-basic way are considered as metaphorical, even when the user of the discourse, in this case the journalist, is not necessarily using this metaphor in a deliberate way. By choosing this identification method we raise the reliability of the quantitative research results, since the intuitive judgment of the researcher is suppressed, even if the use of different dictionaries can lead to a new divergence, as dictionaries are not necessarily compiled according to similar methodological considerations. Even though different approaches to what is the basic and non-basic meaning of a word in the dictionaries can lead to biases in the statistical results, we consider this a risk worth taking in order to acquire justifiable and quantitatively measurable figures for further consideration in our case study, and we refer to Kittay (1987) to justify our decision: "no matter how 'dead,' or conventionalized, metaphors are metaphors none the less” (Kittay 1987: 89; see also Charteris-Black 2004: 18). At the same time "a conventional metaphor in one language may appear highly innovative to a speaker of another language who is not particularly familiar with what has motivated the metaphor, or to the extent to which it constrains literal reading" (Charteris-Black 2004: 19).

A more sophisticated methodology for measuring metaphorical creativity and classifying metaphorically used lexical items was developed recently by Gurin and Belikova (2012). The near-algorithmic procedure, offered in that paper and adopted in the current, allows the role of researcher's language competence to be minimized, thus making clearly intuitive decisions avoidable. 


\section{Metaphor translation}

Taking into account the apparent particularity and culture-specific character of metaphors it seems logical that this figure of speech implies a translation difficulty that cannot be solved by a mere neutral translation strategy. Inevitably, the translator will have to look for an appropriate translational approach to metaphor, and will sometimes even have to resort to the use of substitution, paraphrase and even deletion in order to produce an adequate translation of the ST (see Schäffner 2004).

A pivotal point in research on metaphor translation is the fundamental categorization put forward by van den Broeck (1981: 77), who considers three different approaches to metaphor, namely Translation sensu stricto (when the metaphor of the ST is retained in the TT), Substitution (when the metaphor of the ST is rendered in the TT by another metaphor) and Paraphrase (when the translator decides to explain the metaphor of the ST to the reader without using figurative language), covering the most fundamental approaches to the reproduction of ST metaphors in the TT.

However, this categorization of metaphor translation shifts turns out to be too limited in scope as it leaves out an important and widely used translation option deletion. Van den Broeck's model was therefore further elaborated by Toury (1995: 82-83), who added three more possibilities to the model: omission of an metaphor from the ST, and two possible ways of adding metaphors in the TT, taking into account whether the ST included or not a (non-metaphorical) verbal element on the spot where the new metaphor was created by the translator:

1) metaphor into 'same' metaphor (van den Broeck's Translation 'sensu stricto');

2) metaphor into 'different' metaphor (van den Broeck's Substitution);

3) metaphor into non-metaphor (van den Broeck's Paraphrase);

4) metaphor into 0 (omission of the metaphor in the TT);

5) non-metaphor into metaphor (metaphorization, or the creation of a metaphorical image in the TT);

6) 0 into metaphor (addition, or the creation of a metaphor in an empty place in the ST).

By adding the two latter categories to the model, Toury filled a gap that existed in the analysis of metaphor translation before. By bringing the TT into the research as a starting-point for analysis and not only as a point of reference regarding the ST, the perspective of the research is broadened, an approach that is excellently suited for the cultural and comparative viewpoint we will use in this paper. In other words, we will not look at metaphor translation as "a question of the individual metaphorical expression" but as features of both SL and TL that are "linked to the level of conceptual systems in source and target culture” (Schäffner 2004: 1258). For the purpose of our analysis, we will use the abbreviations T1, T2, .., T6 in our paper to refer to the six categories defined by Toury for metaphor translation, with T1 referring to "metaphor into same metaphor," T2 to "metaphor into different metaphor," etc.

\section{Foreignization and domestication}

In the text above we have constructed a tool to categorize the way the translator handles the metaphorical image itself but this tool does not give us any information on the overall translation strategy of the translator, which means it does not give us 
an answer to the question of whether the translated metaphors are either foreignizing or domesticating. The discussion about the correct way of translating, either by "moving the writer toward the reader" or "the reader toward the writer" (see Schleiermacher 1813/2004: 49) or, in other words, by using a TL- or SL-oriented translation strategy has been going on for ages, but the terms foreignization and domestication have only recently been attached to this discussion, since the appearance of Venuti's (1995) The Translator's Invisibility. According to Venuti (1995/2008: 15-16), foreignizing translation "signifies the differences of the foreign text, yet only disrupting the cultural codes that prevail in the translating language," while domestication produces "the illusion of transparency" by "reducing if not simply excluding the very differences that translation is called on to convey."

Unfortunately, these specifications are not elaborated in great detail and therefore they allow of several interpretations. In this paper we follow the interpretation by Kwieciński (2001: 13-14) and consider all forms of "accommodation of the target text to the established TL/TC concepts, norms and conventions" to be examples of domestication and features of "the introduction into the target text of concepts and language forms that are alien and/or obscure in the target language and culture" as foreignization.

With regard to the translation of metaphor this results in a distinction between three different kinds of translation shifts. In those cases where the metaphorical expression of the ST is retained in the TT, particularly when the translator uses a shift from Toury's first category (T1), despite the availability of a more idiomatic alternative in the TL, we label the translation shift as foreignizing, since the metaphorical expression used by the translator is, in that case, virtually unknown or at least surprising in the target culture (TC).

The label of domesticating translation is attached to those translation shifts where the translator has tried to erase the foreign character of the original text, for instance by replacing the original metaphor by one that is better known and fairly conventional in the target culture (T2), by replacing the original metaphor by a nonmetaphorical explanation (T3) or by totally omitting the metaphorical image of the original (T4). The cases of metaphorization (T5 and T6) in our analysis are also considered as utterances of domesticating tendencies. This is in line with the ideas of Lakoff and Johnson (1980) on conceptual metaphors, who consider metaphors as an instrument to explain complex or abstract novelties through the well-known images each of us has in his/her cultural concepts: "Many of our activities (arguing, solving problems, budgeting time, etc.) are metaphorical in nature. The metaphorical concepts that characterize those activities structure our present reality" (Lakoff and Johnson 1980: 145). If the added metaphor is conventional and well-known to the Russian audience, this is a clear case of adjusting the ST to the expectations of the target readership and therefore domestication. Even when the translator decides to dress up the original text by using a highly original, new metaphor, this new image will inevitably be closer to concepts known in the TC than to those of the source culture (SC), which is again a sign of adaptation to the TC reader's taste and norms.

Apart from foreignizing and domesticating translation shifts the translator also has the possibility to choose a neutral translation strategy, "whenever the translation remains unmarked, i.e., those cases where the translator did not really meet a translation problem and was able to use the most obvious choice of words" (Van Poucke 
2012: 148). Applied to the translation of metaphor, neutral translation means either retaining the metaphor of the original (T1) or, when retention is not possible according to TL norms, adapting the SL metaphor to a TL equivalent of that expression (T2). By a "TL equivalent" in this context we mean a TT metaphor with the level of conventionality or creativity that is neither lower nor higher than the ST metaphor. The conventionality of a particular metaphorical expression can be checked by analyzing the frequency of appearance of both metaphors in their respective languages (see Belikova 2012: 106-109 for a discussion on the degree of metaphorical expressions in terms of conventionality and creativity).

Cases of substitution or adaptation of the ST metaphor by a more conventional one (T2) are culturally determined and usually have to do with idiomatic structures within the SL and TL and the untranslatability of certain metaphorical images into the TC. When, for instance, the English "he was hungry to try" (OE1) is translated by “он испытывал жажду деятельности” [he felt thirst of work] (TE1) in our corpus, we consider this to be neutral translation, since the common equivalent of the English metaphor hunger (a strong desire or craving) is in Russian expressed in this context by thirst. Retaining the image of hunger in Russian would, instead, have produced a highly unconventional and therefore strongly foreignizing translation.

\section{Case study: InoSMI}

In this paper we develop a case study, based on a parallel corpus of 60 original Dutch, English and Finnish journalistic texts with their translations into Russian in order to answer a threefold research question: (1) when and how often does a Russian translator of news texts resort to a foreignizing translation strategy; (2) is there any link between the (central or peripheral) status and prestige of the SL and the choice by the translator to use either a foreignizing or domesticating translation strategy; and (3) is it possible to suggest an explanation for the cases of foreignization in the translated texts?

\subsection{InoSMI}

In order to answer these research questions we compiled a corpus consisting of, on the one hand, 60 translations taken from the popular Russian news site InoSMI and, on the other hand, their STs in Dutch, English and Finnish. InoSMI is chosen for our purpose since it is a Russian Internet project, existing since 2000, which monitors global media (with special attention paid to the press of former republics of the Soviet Union) and provides Russian translations of articles, mostly analytical essays, by international journalists on subjects that might be of interest to Russian-speaking Internet users.

The character of the project has been changing over the years, however, and the translation policy of InoSMI took a turn in March 2009, with the appointment of a new editor-in-chief. Whereas, before March 2009, articles were chosen from a broad range of different news sources in several languages, the new policy nowadays tends to focus more on major languages, which led to a diminished availability of news sources from minor languages such as, for instance, Dutch and Finnish.

Another key feature of the policy change concerns the thematic requirements for the articles to be translated. During the first years of the Internet project the 
majority of translated articles had a direct link to Russian political, economic or social issues. Since March 2009, however, articles have been chosen on a much broader range of subjects that sometimes have only indirect links to Russia. Nevertheless, the main aim of the project remains unchanged, as indicated on the home page - to offer the Russian reader “все, что достойно перевода" [everything that is worth translating] in good translations.

\subsection{The corpus}

In order to study foreignizing tendencies in news translation we compiled a corpus of 120 texts, consisting of three subcorpora, each containing 20 original news texts and their translations, taken from the InoSMI website. The choice of languages has been determined by several considerations with regard to the differences between these languages. On the one hand, we are able to confront translations from a central language, English, with two peripheral ones - Dutch and Finnish. On the other hand, we can also take a number of other oppositions in the comparison. Russia and Finland share a number of geopolitical features and climate conditions that could, in accordance with the ideas of Lakoff and Johnson (1980), lead to the development of a particular kind of metaphorical image, with relatively more images of ice, snow and freezing temperatures for Russia and Finland, and relatively more images of the sea and moderate temperatures for the Dutch and English cultures. At the same time, the Russian language has more parallel linguistic structures with the equally IndoEuropean roots of the two Germanic languages Dutch and English, than with a Finno-Ugrian language, which could also have consequences for the use of metaphors.

The corpus has been compiled in two consecutive steps. Firstly, since the InoSMI project gives considerable attention to news articles written in English, we were able to compile an English corpus that consists of recent ST and their translations, collected within a period of barely 10 weeks (August 1 to October 16, 2012). We limited the number of selected editions to two of the main newspapers in InoSMI's policy, one British, The Guardian, and one American, The New York Times. Both newspapers are listed among the ten most frequently used newspapers according to the "Каталог изданий" [Catalog of publications] on the home page of the InoSMI project and, moreover, they are considered to be two of the most influential newspapers in their respective sector of the globe. We selected ten articles from both newspapers, which met two key criteria: the articles (1) had to be analytical and (2) had to be discussing Russian subjects. The list of selected articles (OE1 to OE20) and their translations (TE1 to TE20) is shown in the Appendix.

Secondly, for the Dutch and Finnish subcorpora, we could not fall back on the same methodology, since the translation of Dutch and Finnish articles on the InoSMI website all but dried up in March 2009. As a consequence, we had to select 20 translations from Dutch and Finnish according to other criteria. All 40 articles were selected over the period 2005-2009, with only two exceptions: since 2009 one Finnish article was translated and published in 2010, and something similar goes for the translations from Dutch, with one article translated and published in 2011. Both relatively recent articles were added to the corpus, an overview of which (the texts OD1 to OD20, TD1 to TD20, OF1 to OF20 and TF1 to TF20) can be found in the Appendix. 
We openly acknowledge the asymmetry of the two subcorpora, including both recent and older articles and translations. But as the use of metaphor in original and translated texts from different cultures is our main focus here, we don't believe that the asymmetry will affect our findings much. All the more so as a major change in the translation strategy into Russian is unlikely to have happened between 2005 and 2012.

\subsection{Methodology}

As we explained earlier, we decided to use an adapted version of MIP(VU) in order to detect the metaphors in all 120 texts of our corpus. All the subsets of STs and TTs were searched independently for metaphorically used words and expressions. The dictionaries used were the following: the Oxford Dictionary of English ${ }^{5}$ for the English STs, the van Dale online dictionary ${ }^{6}$ for the Dutch STs, the MOT Kielitoimiston sanakirja ${ }^{7}$ (MOT Dictionary of Contemporary Finnish) for the Finnish STs and

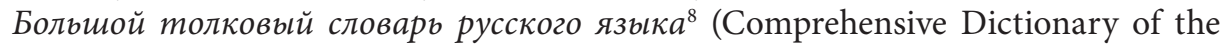
Russian language) for the different Russian TTs.

The metaphors in the subcorpora were identified in the STs and TTs independently from each other, which allowed us to get a full picture of the use of metaphors in both the originals and the translations. Subsequently, we compared the metaphors in both subsets of texts in order to form a set of ST/TT pairs according to the categorization proposed by Toury.

Finally, we attached an additional label to each of the pairs, depending on the translation strategy used by the translator. As we explained above, we labeled the translation as domesticating whenever we could establish a relationship between the ST- and the TT-element that meets Toury's categories 3, 4, 5 or 6, since all these categories concern either the omission or addition of a metaphorical expression in an attempt to conform the text to the taste of the TT reader, subsequently erasing the foreign character of the original. For the cases of substitution of ST metaphors by other metaphors in the TT (T2), we checked the level of conventionality of the replacing metaphor and came to the conclusion that we were dealing with neutral translation in all cases of $\mathrm{T} 2$ in the corpus.

However, it soon became clear that Toury's first category of translation sensu stricto contained both examples of foreignization and neutral translation, and therefore we made a further division of this category into two subcategories, "T1N" for the cases of neutral translation, when the reader is equally familiar with the metaphor in the ST and TT, and "T1F" for the cases of foreignization, when the metaphorical expression in the TT turns out to be more surprising and less conventional for the TT reader than the ones used in the ST for the ST reader. The examples of T1F are selected for further qualitative analysis in the second part of our paper.

\section{Quantitative analysis}

At first glance, the quantitative analysis of our data reveals a marked difference in the use of metaphorically used words and expressions between the six subcorpora, as can be seen in Table 1 below. The absolute frequency of metaphors in a subcorpus is given under "MET," the total number of words in the subcorpus under "WORDS" and the relative frequency of metaphors under "\%MET." 
TABLE 1

Absolute and relative frequencies of metaphors in the different subcorpora

\begin{tabular}{|l|c|c|c|c|c|c|c|}
\hline ST & MET & WORDS & \%MET & TT & MET & WORDS & $\%$ MET \\
\hline OD & 901 & 14,830 & $6.1 \%$ & TD & 885 & 13,472 & $6.6 \%$ \\
\hline OE & 1,702 & 18,494 & $9.2 \%$ & TE & 1,244 & 17,230 & $7.2 \%$ \\
\hline OF & 1,020 & 10,282 & $9.9 \%$ & TF & 1,215 & 14,830 & $8.2 \%$ \\
\hline
\end{tabular}

Each of the subcorpora contains a number of metaphorically used words between 6.1 and $9.9 \%$ of the total number of words, which seems to be in line with earlier findings by Steen, Dorst, et al. (2010: 44) in a corpus of news texts. Steen's team of four independent analysts had an "unanimous agreement for metaphor" in $15 \%$ of the cases, with an extra percentage of $5.1 \%$ of possibly metaphorical "items where no inter-analyst consensus was reached." Our case study led to an overall lower degree of metaphoricalization in the different subcorpora, but this can partly be explained by the fact that the analysis by Steen, Dorst, et al. included all word sorts, while we restricted our search to nouns, verbs and adjectives only, and, moreover, excluded personification.

Table 2 displays the distribution of the different translation choices within one language pair (OD-TD; OE-TE; OF-TF), according to the aforementioned methodology, based on Toury's 6 categories, including a division between neutral and foreignizing cases of translation sensu stricto (T1). The total number of features where a metaphor is used either in the ST (T3-T4), in the TT (T5-T6) or in both texts (T1-T2) is indicated under "\# MET."

TABLE 2

Relative distribution of metaphor pairs, according to Toury's categorization

\begin{tabular}{|l|c|c|c|c|c|c|c|c|}
\hline & T1N & T1F & T2 & T3 & T4 & T5 & T6 & \# MET \\
\hline DUT & $31.8 \%$ & $1.1 \%$ & $10.9 \%$ & $27.5 \%$ & $1.3 \%$ & $26.2 \%$ & $1.3 \%$ & 1,242 \\
\hline ENG & $30.5 \%$ & $0.7 \%$ & $19.7 \%$ & $33.5 \%$ & $2.8 \%$ & $12.5 \%$ & $0.4 \%$ & 1,954 \\
\hline FIN & $23.9 \%$ & $1.8 \%$ & $26.1 \%$ & $14.0 \%$ & $3.5 \%$ & $20.0 \%$ & $10.7 \%$ & 1,472 \\
\hline
\end{tabular}

\subsection{Domesticating metaphor translation}

At first sight, the number of cases of omission (T3 and T4) or addition (T5 and T6) of metaphors seems very high throughout the corpus $(56.2 \%$ for Dutch-Russian, $49.2 \%$ for English-Russian and $48.2 \%$ for Finnish-Russian) but this can partly be explained by the significant differences that exist between the language pairs in our investigation. Since we are dealing with structurally different languages the particularities of language evolution in each of them has given rise to a certain number of metaphorically used expressions that, on the one hand, do not have an equivalent metaphor in another language, in this case Russian and, on the other, are no longer active and therefore used unintentionally by authors. MIP(VU) does detect metaphors that belong to the categories of "Tired," "Sleeping," "Dead" and even "Buried" metaphors (Goatly 1997/2011: 29-35), but, for our qualitative analysis, they are insignificant as they are hardly the result of a deliberate translation strategy. For reasons of objectivity and verifiability, however, we retained these inactive metaphors in our quantitative data, acknowledging how difficult it is to draw "a borderline between 
the literal and the metaphorical" (Goatly 1997/2011: 7) otherwise. A detailed analysis of these cases of omission and addition would go far beyond the scope of this paper.

\subsection{Neutral metaphor translation}

Not only is the number of cases of domestication high in our three subcorpora, the number of cases of neutral translation of metaphorical expressions is high as well: 42.7\% for Dutch-Russian, 50.1\% for English-Russian and 50.0\% for Finnish-Russian. These neutral translations belong to two different categories and are diverse in nature.

First, we have the large group of expressions that are translated sensu stricto without any loss of meaning or change in the level of conventionality. Here, we are dealing with examples where both the ST and the TT share similar metaphorical expressions in roughly the same way and with a comparable degree of conventionality. The importance of this kind of metaphor pair is not to be underestimated: in $31.8 \%$ of the translations from Dutch, 30.5\% from English and 23.9\% from Finnish, the translator took no risk in retaining the image of the ST in the TT. Since we are dealing with news text translations that have to be delivered at relatively high speed, taking the first translation solution available is an obvious choice for the translator who usually pays less attention to style than in the case of literary translation.

Secondly, a smaller but nevertheless respectable number of neutral translations belong to Toury's second category: in $10.9 \%$ of the translations from Dutch, $19.7 \%$ from English and 26.1\% from Finnish the metaphorical images differ, but these are all cases where a close or literal translation of the SL metaphorical expression would be unacceptable in the TL, which led the translator to resort to a TL equivalent of the ST expression with a comparable degree of conventionality.

\subsection{Foreignizing metaphor translation}

Finally, our corpus also contains a small number of translated metaphors that meet our definition of foreignization, which means the metaphor in translation has a higher degree of originality for the TT reader than the one used in the ST had for its reader. In 54 cases out of a total of more than 44,000 words, the translators have deliberately preserved an image of the source culture that could have been replaced by a more common and recognizable metaphor in Russian.

Since English currently plays the role of global lingua franca, one could expect that translators from English are more tempted than others to borrow and retain the images from the ST. Especially in news texts the Russian language is currently being enriched by large amounts of English loanwords that are used in different types of discourse. Our case study, however, does not confirm this hypothesis, since the relative presence of foreignizing translations in the translated corpus is significantly lower in the English-Russian (0.7\%) than in the Dutch-Russian (1.1\%) and FinnishRussian (1.8\%) subcorpora. In other words, the translators do not expect their readers to be more familiar with metaphorical images from English texts than from more peripheral languages, hence typical English metaphorical expressions are, in general, domesticated in the same way as in the other subcorpora, and even to a larger extent.

In our opinion, two possible explanations for this translational behavior can be found on a more pragmatical level. First, we can ascertain in the Appendix that the 
Russian translations of English ST are, on average, released on the next day after publication in the English or American newspaper. This does not leave the translator much time to think about the most adequate way to translate a metaphor and subsequently, the image of the original is usually retained, despite the foreignizing character of the translation. Obviously, this hypothesis is only valid with regard to the English-Russian corpus, since the translations of Dutch and Finnish articles are sometimes published with a much bigger time gap.

Secondly, we have to acknowledge that the foreignizing translation strategy could also serve a more ideological purpose, as we will try to illustrate in the next few paragraphs. Especially in translation from English into Russian, one could expect translators to have ready-made solutions for most translation problems, including the transfer of metaphors and images. In our opinion, it is only natural to assume that more (and probably more experienced) translators from English are available to the InoSMI project, which should result in more fluent translations for this SL, and therefore fewer cases of incidental or stylistically unacceptable foreignization, even with the stringent deadlines imposed upon the translators.

In the following paragraphs a qualitative analysis of the 54 cases of foreignization will shed light on the use of this particular translation strategy in our corpus.

\section{Qualitative analysis: foreignizing the translation of metaphors}

When an experienced translator resorts to foreignization we can expect that this is most probably done intentionally, especially in literary translation, where the purpose of a foreignizing translation strategy is mainly to provide the reader with a translation that is maximally close to the ST, retaining the specific stylistic and lexical choices made by the author, and confronting the reader with certain typical features of the SC and SL. In our case study, however, we are dealing with news texts that also contain a number of stylistic and lexical peculiarities of the SC or SL but, as a rule, the retention of these characteristics is not equally important for the translator since the rendering of the content is far more important to him than the style of the message.

For most of the translated articles we cannot check the identity of the translator, hence we cannot ascertain whether the foreignizing strategy results from a lack of experience by the translator or rather his or her preference for foreignization. A detailed analysis of the cases of foreignizing translation, however, reveals a few tendencies that have too much in common to be mere coincidence. It is striking, for instance, how most cases of foreignizing metaphor translation occur in abstracts of the ST that contain direct or indirect criticism towards the Russian state, Russian society or its leaders, as if to confront the Russian reader with the way foreigners usually talk about Russia in their press articles.

Western journalists have maintained their critical voice towards Russia throughout the $20^{\text {th }}$ century. This negative attitude was a direct result of the Russian revolution of 1917, and the hostility towards the Soviet state intensified after World War II, with the beginning of the Cold War. The impression prevails in Russia that the fall of the Soviet empire did not really change the West's critical attitude towards the country and the state for the better. Our corpus, at least, seems to confirm this general impression, as at least 18 of the 60 translated articles treat rather delicate themes for Russian readers, such as the lack of democracy under Putin, Russian nationalism 
and the behavior of Russian tourists abroad. In general, the cases of foreignization in the translation can be centered around three major themes: (1) the Russian state or nation; (2) Russian society; (3) the Russian leader(s).

\subsection{Metaphors with regard to the Russian state}

Our corpus of STs contains several metaphorical images that are used to depict the Russian state or nation, and some of them are retained in translation, despite the fact that a similar metaphorical expression is not really common in Russian and will certainly attract the reader's attention. Metaphors are, for instance, used in the STs to depict Russia as an instrument that has been (economically) written off in the past (TD14) or a ship that is (blindly, the author suggests) following the compass of mercantilism (TD14).

The majority of cases of foreignization, however, lie in metaphorical expressions that link the Cold War enemy with what journalists consider to be inappropriate behavior towards the outside world. In one of the articles Russia is described as a seducer of the "women" in NATO's "harem" (TD1), in another as an animal abuser who is trying to "muzzle" the "dog" that is representing the free press in Russia (TD14). Equally foreignizing is the image of Russia as a traveler who had the possibility to choose the "pink path" the West had hoped for, but refused to do so in order to go its own (anti-Western) way (TD14).

A recurring portrait is that which describes the Russian nation as a mentally or physically sick person who could represent a serious threat to the West. In examples (1) and (2) we can see how the translator has chosen to retain the image of the original, in order to give the Russian reader an impression of the way foreigners think about their state:

(1) OD14: Ruslands antwoord is een bijna paranoïde wantrouwen tegen het Westen [Russia's answer is an almost paranoid distrust of the West]

TD14: Поэтому Россия отвечает Западу почти параноидальным недоверием [Russia therefore answers to the West with an almost paranoid distrust]

(2) OF5: Putin johtaa sairasta suurvaltaa

[Putin is leading a sick superpower]

TF5: Путин управляет больным государством

[Putin is leading a sick state]

Examples (3) and (4) refer to the Russian state using another metaphorical image of Russia. The TT readers are, without any doubt, acquainted with the image of the "Russian bear," evidence of which is that the leading party of the country, Единая Россия [United Russia] chose the mythical animal to figure in the center of its party logo. In our corpus, however, we are dealing with some atypical associations with the image of the bear, and the translator uses a foreignizing translation strategy to transfer the message of the article to the reader:

(3) OD19: Wie weet welk Europees land pakweg volgende maand de toorn van de Russische president wekt: de beer is los

[Who knows which European country will rouse the anger of the Russian president in the next month or so: the bear is loose]

TD19: Кто знает, какая европейская страна, возможно, уже в следующем месяце вызовет гнев российского президента: медведь сорвался с цепи 
[Who knows which European country is most likely to provoke the Russian president's anger next month: the bear has broken loose]

(4) OF9: Venäjän uhka on Suomelle se esi-isiemme karhu, jota ei saa sanoa ääneen, koska muuten karhu tulee

[The Russian threat to Finland is like a big bear to our ancestors, whose name mustn't be said out loud as otherwise it will come at you]

TF9: Угроза для Финляндии, исходящая от России, - это тот медведь для наших предков-охотников, имя которого нельзя произносить вслух ни в коем случае: иначе зверь нападет сам

[The Russian threat to Finland is like a big bear to our hunting ancestors, whose name should not be said out loud, otherwise it will attack]

Example (4) deserves a complementary explanation since we are dealing here with a local Finnish culture-bound image. The mentioning of a bear in this context is a strong reference to danger.

\subsection{Metaphors with regard to Russian society}

Other fragments that contain unnatural, foreign-sounding metaphors in Russian translation are thematically linked to descriptions of Russian society, in the broadest sense of this term, including politics, the economy and social issues. Western opinions about Russia being the country of grey bureaucrats (TE1) are retained in translation, as well as references to the wild capitalism that replaced the Soviet system (TE5) and the Russian economy that is, according to the Western journalist, much worse equipped than China's one to reap the benefits of WTO membership (TE7).

Both the Russian economy and international politics are commonly linked in Western press articles to the traditional image the reader has about the cold and frosty Russian climate:

(5) OE7: The economic climate is much frostier than it was in 2001

TE7: Экономический климат сейчас гораздо более «прохладный», чем в 2001 году

[The economic climate is now far much colder than in 2001]

(6) OF8: Kylmiä tuulia alkoi purjehtia Varsovan ja Moskovan suhteisiin Puolan päästyä kuusi vuotta entisen Varsovan liiton vihollisen, Naton siipien suojien alle. [...] Puolan astuminen yhdeksän muun uuden valtion kanssa Euroopan unionin ovesta sisälle runsas vuosi sitten vappuna viilensi taas entisten ystävävaltioiden suhteita

[Cold winds have begun to blow in relations between Warsaw and Moscow after Poland got under the wing of NATO six years ago, the former enemy of the Warsaw Pact. [...] Poland's decision to join the EU, together with 9 new members more than a year ago on May Day, has cooled relations between the two formerly friendly states]

TF8: Холодные ветры вновь повеяли с сфере контактов Варшавы и Москвы после того, как Польша попала шесть лет назад под крылышко заклятого врага стран-членов Варшавского договора - НАТО. [...] Вступление чуть более года назад 1 мая Польши в числе 9 новых членов в ЕС вновь «подморозило» связи двух прежних дружественных государств

[Cold winds have begun to blow again in relations between Warsaw and Moscow after Poland, six years ago, got under the wing of the sworn enemy of the member 
states of the Warsaw Pact - NATO [...] When Poland joined the EU more than a year ago on May Day among 9 new members, relations between the two formerly friendly states "froze down" again]

In examples (5) and (6) the translator acknowledged the strangeness of the image for a Russian reader, which is the reason why he or she uses quotation marks in the translation.

Furthermore, Russian international politics are described as extremely defensive with the use of a double metaphor in one and the same fragment, one referring to a hedgehog attitude and another to the construction of high border fences, two images not commonly used in Russian with regard to geopolitics:

(7) OF10: Nyt olisi jo korkea aika siirtyä pois siilipuolustuksesta ja ymmärtää, että Suomen ja Venäjän suhteissa myös Suomi voi olla aktiivinen osapuoli. [...] Vaikka viisumivapauteen ei vielä voida mennä, rajaa voidaan muuten eri tavoin madaltaa [It is high time to abandon the politics of a hedgehog defense and to realize, that in Finnish-Russian relations, Finland can be an active party. [...] Though abolishing the visa regime is still impossible, the border fences could somehow be lowered] TF10: Пора оставить политику «ежовой» защиты и понять, что в связях Финляндии и России сама Финляндия может быть активной стороной. [...] Полный отказ от виз сейчас действительно невозможен, но ведь пограничные заборы можно немного опустить разными способами

[It is time to abandon the politics of a "hedgehog" defense and to realize that Finland itself can be an active party in Finnish-Russian relations. [...] A complete rejection of visa is currently, indeed, impossible, but it is possible to lower the border fences a little in different ways]

Three other instances where the deficiencies of the Russian society are highlighted in Finnish, are also repeated in the translations. In these fragments the reader is presented with an image of a country that suffers from uncontrolled money flows (8), a shortage of democratic traditions in politics that are likened to a theatre play (9) and a broken spine at the level of social relations (10):

(8) OF11: Venäjän vahva talous perustuu ennen kaikkea sen valtaviin raaka-ainevarantoihin, ja energian hintojen nousun myötä rahaa virtaa Äiti Venäjälle ikkunoista ja ovista

[The strong Russian economy is based primarily on enormous amounts of raw resources, and, due to the rise in energy prices, money now flows into Mother Russia through windows and doors]

TF11: Укрепление экономических позиций России зависит от наличия в стране огромных запасов сырья, а рост цен на энергоносители привлек поток денег в Россию-матушку, да такой, что они текут в окна и в двери!

[The consolidation of Russia's economic position depends on the presence in the country of enormous amounts of resources, and the rise in prices of energy resources attracted a flow of money into Russia, to such an extent that money now flows into windows and doors]

(9) OF12: Demokratian kulissien rakentamisella on kiire, sillä duuman vaalit ovat runsaan vuoden päästä ja presidentinvaalit keväällä 2008

[Building the stage wings of democracy is an urgent matter, because the State Duma elections are every other year and presidential elections will take place in the spring of 2008 already] 
TF12: Демократические кулисы необходимо создать очень быстро: выборы в Госдуму не за горами, да и президентские пройдут уже в 2008 году

[The stage wings of democracy have to be created very rapidly: the State Duma elections are not far off and presidential (elections) will take place in 2008 already]

(10) OF5: Vaikea on suhtautua ydinasevaltaan, jonka sosiaalinen ja terveydellinen selkäranka on murtumassa ja joka kuitenkin jatkaa uhitteluaan kuin kylmän sodan kiihkeimpinä hetkinä

[It is difficult to forge relationships with a nuclear power, whose healthcare and social policy spine is broken and which continues to threaten as in the most tense times of the Cold War]

TF5: Трудно строить отношения с ядерной державой, хребет которой здравоохранение и социальная политика - сломан, и которая продолжает угрожать, как в самые напряженные времена «холодной войны»

[It is difficult to forge relationships with a nuclear power whose spine - healthcare and social policy - is essentially broken, and which continues to threaten as in the most tense times of the "Cold War"]

\subsection{Metaphors with regard to the Russian leader}

Finally, we also found a number of cases in our corpus where the Russian translator retained the Western metaphors with regard to the Russian leader. Here again, we are dealing with instances where Vladimir Putin is treated in a rather critical manner, which is not in line with the common images the Russia media use in reference to their president. Putin is described in the articles as an icy (11) macho-man (12), who has little respect for the relatively small neighbor (Finland) (13):

(11) OD10: Humor in het Kremlin, daar is de wereld de afgelopen eeuw te weinig op getrakteerd. Maar deze humor is wel van de ijskoude soort. Ook ijskoud maar bloedserieus is Poetin als een Italiaanse journalist hem vraagt [...]

[Humor in the Kremlin, the world has got very little of that during the past century. But this humor is of a freezing cold kind. Equally freezing cold but utterly serious is Putin when an Italian journalist asks him [...] ]

TD10: Юмор в Кремле. За последнее столетие мир слишком редко такое слышал. Но этот юмор холоден, как лед. Таким же холодным, но совершенно серьезным стал Путин, когда итальянский журналист спросил его [...]

[Humor in the Kremlin. In the past century the world has too rarely heard that. But this humor is as cold as ice. Equally cold, but dead serious is what Putin got when an Italian journalist asked him [...] ]

(12) OE12: It may well be the most personally wrenching question that Russia's machoman in chief has had to face since the start of his third term in May

TE12: Возможно, это самый болезненный личный вопрос, с которым сталкивался верховный российский мачо с тех пор, как в мае начался его третий президентский срок

[Maybe it is the most painful personal question that the supreme Russia's macho has had to face since his third presidential term started]

(13) OF10: Vasta pikku hiljaa täällä on alettu ymmärtää, että suurvallan johtajalla on tärkeämpääkin tekemistä, kuin paapoa Suomen kaltaista kansainvälisen politiikan pikkutekijää, joka ei edes aiheuta samalla tavalla ongelmia kuin useimmat muut Venäjän naapurit

[Only gradually did they start to realize here that the leader of a great power has more important tasks than indulging such minor participants of international 
politics such as Finland, which doesn't even give a lot of trouble, unlike Russia's other neighbors]

TF10: Постепенно у нас начали осознавать, что у главы великого государства есть более важные задачи, нежели нянчиться с небольшим фактором международной политики, каковым Финляндия и является

[Little by little we began to realize that the head of a great power has more important tasks than to pamper the small factor in international politics that Finland appears to be]

Quite provocative are the metaphorical images in the following two examples. In the former, president Putin is depicted as a disrespectful man, who lets the hostess (in this case Tarja Halonen who was the Finnish president at the time) wait while she keeps her coffee hot (14). The latter fragment compares the Russian president with an "heir to the throne," which includes an indirect reference to the way he came to power, as if he did not "earn" his place, but inherited it in the way emperors and kings get their power and prestige through parentage (15):

(14) OF10: On häntä odotettukin. Tarja Halosella oli Kultarannassa pannu kuumana jo koko viime kesän

[He was expected. Tarja Halonen was already in Kultaranta with the hot coffee pot all last summer long]

TF10: А его ожидали. Тарья Халонен не снимала с подогрева кофейник в своей летней резиденции Култаранта (Золотой берег) все прошлое лето [He was expected. Tarja Halonen did not remove the coffee pot from the heating element in her summer residence Kultaranta (Golden Shore) all summer long]

(15) OD6: Hier veel vlaggen, wapens en medailles, beschenen door kolossale lichtbakken met de gezichten van Jeltsin en kroonprins Poetin

[Many flags, arms and medals here, illuminated by colossal light boxes with the faces of Yeltsin and heir to the throne Putin on them]

TD6: В зале много флагов, гербов и медалей, на которые падает свет от колоссальных светящихся портретов Ельцина и его дофина Путина

[In the hall there are many flags, arms and medals, on which light is shed from the colossal luminous portraits of Yeltsin and his heir to the throne Putin]

\section{Conclusions}

In this paper we looked at the use of metaphors in journalistic texts and their translations into Russian, and tried to explain the use of foreignization by the Russian translators in a number of cases. We assumed that foreignizing translation strategies would be more often present in translations from the highly prestigious English into Russian then from minor languages as Dutch and Finnish, since metaphorical images from English are currently broadly dispersed across other languages and cultures through different media (literature, film and Internet resources) in a process of rapid globalization.

In order to check the validity of our presumption we first constructed a corpus of 120 original and translated news articles in four different languages (Dutch, English, Finnish and Russian), taken from the Russian news website InoSMI and the corresponding sources for the Russian translations. Metaphors were detected in the corpus according to the methodology proposed in Gurin and Belikova (2012), based on the MIP(VU) procedure. Subsequently, the metaphors in the TT were mutually 
compared with the metaphors in the ST and the metaphor pairs in both ST and TT were categorized in accordance with the model proposed by Toury (1995). This model takes into account six different possibilities of translation of metaphors, among which we retained the cases of translation sensu stricto (T1) for further analysis into foreignizing translation.

The quantitative results of the case study revealed a relatively low number of cases of foreignization throughout the three different subcorpora, ranging from $0.7 \%$ in the translations from English to $1.8 \%$ from Finnish, which means that our presumption about the possible influence of English on the translations was not confirmed by the data. The translations from English, on the contrary, proved to contain relatively less cases of foreignization then the other two subcorpora.

Hence a qualitative analysis of the cases of foreignization was conducted in order to find an explanation for the use of foreignization in the translations, since the prestige of lingua franca English apparently was not a decisive factor for the translators. Russian translators did, indeed, reject the use of common (and idiomatic) metaphorical images in a number of cases, and chose to retain the images of the originals.

An analysis of the contexts in which the metaphors of the originals were retained revealed that this was the case in a specific number of discourses, mainly when the Western journalist used an image that was, on the one hand, virtually unknown to the Russian reader and, on the other hand, contained a certain amount of criticism towards the Russian state, society and/or the leader of the country. By employing foreignizing translation strategies in these cases, the translators seem to pursue a specific purpose, namely the confrontation of the Russian reader with the specific discourse that is developed in the West to refer to Russian reality. By presenting the reader with "everything that is worth translating" and not interfering with the opinions and the metaphorical images contained in the ST, the editors of InoSMI achieve a double goal. Not only are they able to express opinions that are not commonly present in other media in Russia, but they also give the reader an impression of the stylistic features of Western reporting on the former Cold War opponent, preserving in this way the reputation of objectivity and integrity of this major player on the Russian Internet market.

\section{NOTES}

1. The VU in MIPVU stands for 'Vrije Universiteit' (Free University) Amsterdam, which is the Dutch official name of 'VU University Amsterdam,' not to be confused with the 'University of Amsterdam' (UvA).

2. We use codes throughout the paper to refer to the articles in our corpus. "O" refers to "original," "T" to "translated." Moreover, the letters "D," "E" and " $F$ " refer to the source languages Dutch, English and Finnish respectively. The figure, finally, refers to the number of the text. A full list of articles is attached to the paper in the Appendix.

3. "V-term" is the terminology used by Goatly to refer to the "Vehicle," the "conventional referent of the unit" (Goatly 1997/2011: 9) in a metaphorical expression, or, in other words, the specific domain with which a more abstract concept is compared.

4. InoSMI. www.inosmi.ru.

5. Oxford Dictionary of English. http://oxforddictionaries.com.

6. van Dale online dictionary. http://www.vandale.be.

7. MOT Kielitoimiston sanakirja. http://www.kielikone.fi.

8. Большой толковый словарь русского языка. http://gramota.ru. 


\section{REFERENCES}

Barhudarov, Leonid (1975): Jazyk i Perevod [Language and Translation]. Moscow: Meždunarodnye otnošenija.

Belikova, Alexandra (2012): 'Money flows into windows and doors' or 'Money flows like a river.' Identifying Translation Strategies by the Yardstick of Metaphorical Creativity. In: Hannu Kemppanen, Marja Jänis and Alexandra Belikova, eds. Domestication and Foreignization in Translation Studies. Berlin: Frank \& Timme, 101-120.

Charteris-Black, Jonathan (2004): Corpus Approaches to Critical Metaphor Analysis. New York: Palgrave Macmillan.

Dickins, James (2005): Two models for metaphor translation. Target. 17(2):227-273.

Goatly, Andrew (1997/2011): The Language of Metaphors. $2^{\text {nd }}$ edition. London/New York: Routledge.

Gurin, Grigory and BeLikova, Alexandra (2012): Metodika ocenki konvencional'nosti metaforičeskih vyraženij: ot intuitivistskih kriteriev k operacional'nym [A procedure for evaluating degree of conventionality of metaphor expressions: from intuition to operational criteria]. In: Andrej Kibrik, Vladimir Belikov, Igor Boguslavsky, et al., eds. Computational Linguistics and Intellectual Technologies. Papers from the Annual International Conference «Dialogue» (2012). Issue 11. Volume 1 of 2. Main conference program. Moscow: Russian State University for the Humanities, 187-197. http://www.dialog-21.ru/digest/2012/ pdf1.

Kittay, Eva Feder (1987): Metaphor: Its Cognitive Force and Linguistic Structure. Oxford: Clarendon Press.

Kövecses, Zoltán (2010): Metaphor. A practical introduction. Oxford/New York: Oxford University Press.

KwIECIŃski, Piotr (2001): Disturbing Strangeness. Foreignisation and Domestication in Translation Procedures in the Context of Cultural Asymmetry. Toruń: EDYTOR.

LAKoff, George and Johnson, Mark (1980): Metaphors We Live By. Chicago/London: University of Chicago Press.

Pragglejaz Group (2007): MIP: A method for identifying metaphorically used words in discourse. Metaphor and Symbol. 22(1):1-39.

SCHLEIERMACHER, Friedrich (1813/2004): On the different methods of translating. In: Lawrence Venuti, ed. The translation Studies Reader. London/New York: Routledge, 43-63.

SCHÄFfNER, Christina (2004): Metaphor and translation: some implications of a cognitive approach. Journal of Pragmatics. 36:1253-1269.

Steen, Gerard J., Dorst, Aletta G., Herrmann, J. Berenike, et al. (2010): A Method for Linguistic Metaphor Identification. Amsterdam/Philadelphia: John Benjamins.

Toury, Gideon (1995): Descriptive Translation Studies and beyond. Amsterdam/Philadelphia: John Benjamins.

VAN DEN BROECK, Raymond (1981): The limits of translatability exemplified by metaphor translation. Poetics Today. 2:73-87.

Van Poucke, Piet (2012): Measuring Foreignization in Literary Translation: An Attempt to Operationalize the Concept of Foreignization. In: Hannu Kemppanen, Marja JänIs and Alexandra Belikova, eds. Domestication and Foreignization in Translation Studies. Berlin: Frank \& Timme, 139-158.

Venuti, Lawrence (1995/2008): The Translator's Invisibility. A History of Translation. London/ New York: Routledge. 
APPENDIX

Corpus of newspaper articles, used in the paper

\begin{tabular}{|c|c|c|c|}
\hline Code & Article & Source & Date \\
\hline OD1 & "Raketschild is lakmoesproef voor onze relaties" & De Standaard & 14.02 .2011 \\
\hline TD1 & $\begin{array}{l}\text { ЕвроПРО - лакмусовая бумажка для наших } \\
\text { отношений }\end{array}$ & ИноСМИ & 18.02 .2011 \\
\hline OD2 & Oosten voelt zich NAVO-woestijn & NRC Handelsblad & 24.09.2009 \\
\hline TD2 & $\begin{array}{l}\text { Восточная Европа чувствует себя пустыней } \\
\text { НАТО }\end{array}$ & ИноСМИ & 28.09.2009 \\
\hline OD3 & In Rusland is het nog echt "the sky is the limit" & De Standaard & 29.12.2007 \\
\hline TD3 & $\begin{array}{l}\text { В России поистине беспредельные } \\
\text { возможности }\end{array}$ & ИноСМИ & 14.01.2008 \\
\hline OD4 & Milieuparadijs Baikalmeer loopt gevaar & NRC Handelsblad & 13.07.2007 \\
\hline TD4 & Сибирская Ривьера & ИноСМИ & 25.12.2007 \\
\hline OD5 & Geleerdenstadje overleeft door commercie & NRC Handelsblad & 11.07.2007 \\
\hline TD5 & $\begin{array}{l}\text { Городок ученых выживает благодаря } \\
\text { коммерции }\end{array}$ & ИноСМИ & 11.12 .2007 \\
\hline OD6 & $\begin{array}{l}\text { Het Jeltsinmuseum is een eretempel voor een groot } \\
\text { man }\end{array}$ & NRC Handelsblad & 12.07.2007 \\
\hline TD6 & В музее Бориса Ельцина чтят великого человека & ИноСМИ & 16.11.2007 \\
\hline OD7 & Goelag-verleden nu verlaten openluchtmuseum & NRC Handelsblad & 04.07.2007 \\
\hline TD7 & $\begin{array}{l}\text { ГУЛАГ сегодня: заброшенный музей под } \\
\text { открытым небом }\end{array}$ & ИноСМИ & 13.11.2007 \\
\hline OD8 & $\begin{array}{l}\text { Poetin speelt een gevaarlijk spel. Wat als hij } \\
\text { verliest? }\end{array}$ & Trouw & 24.08.2007 \\
\hline TD8 & $\begin{array}{l}\text { Путин играет в опасную игру. А что, если он } \\
\text { проиграет? }\end{array}$ & ИноСМИ & 28.08.2007 \\
\hline OD9 & Daar komen de Russen & NRC Handelsblad & 27.06.2007 \\
\hline TD9 & Русские идут... & ИноСМИ & 06.07.2007 \\
\hline OD10 & Intimidatie en humor uit het Kremlin & NRC Handelsblad & 08.06.2007 \\
\hline TD10 & Запугивание и юмор из Кремля & ИноСМИ & 20.06.2007 \\
\hline OD11 & Onderschepte raket valt wél op Europa & NRC Handelsblad & 01.05 .2007 \\
\hline TD11 & Перехваченная ракета все же упадет на Европу & ИноСМИ & 24.05 .2007 \\
\hline OD12 & Wereldvrede niet nabij met raketschild in Polen & Trouw & 22.05.2007 \\
\hline TD12 & $\begin{array}{l}\text { Система ПРО в Польше не сделает мир } \\
\text { безопаснее }\end{array}$ & ИноСМИ & 24.05.2007 \\
\hline OD13 & De bescheiden dictator & NRC Handelsblad & 05.04 .2007 \\
\hline TD13 & Скромный диктатор & ИноСМИ & 06.04.2007 \\
\hline OD14 & Rusland is opgestaan, wen er maar aan & De Volkskrant & 25.01.2007 \\
\hline TD14 & Россия встала на ноги - привыкайте & ИноСМИ & 31.01 .2007 \\
\hline OD15 & "Geen contract, geen gas" & De Standaard & 28.12.2006 \\
\hline TD15 & Александр Медведев: “Нет контракта, нет газа” & ИноСМИ & 28.12.2006 \\
\hline OD16 & Gazprom dreigt met escalatie gascrisis & De Standaard & 28.12.2006 \\
\hline TD16 & $\begin{array}{l}\text { Угроза “Газпрома”: Эскалация газового } \\
\text { конфликта }\end{array}$ & ИноСМИ & 28.12.2006 \\
\hline OD17 & Gazpromium-210 & NRC Handelsblad & 12.12.2006 \\
\hline TD17 & Газпромиум-210 & ИноСМИ & 18.12 .2006 \\
\hline OD18 & Flahaut stelt rol Navo ter discussie & De Standaard & 16.05 .2006 \\
\hline TD18 & Министр обороны Бельгии выносит на & ИноСМИ & 19.05.2006 \\
\hline
\end{tabular}


OD19 Europa denkt weer nucleair

TD19 Европа снова думает о ядерной энергетике

OD20 We kunnen het klimaat beheersen

TD20 Управлять климатом возможно

OE1 Evgeny Lebedev: My Soviet childhood

TE1 Евгений Лебедев: мое советское детство

OE2 Russia denies knowledge of spy plot as US man appears in court on charges

TE2 Россия отрицает причастность арестованных в США граждан к российской разведке

OE3 Top London law firms profit from feuding Russian oligarchs

TE3 Ведущие юристы Лондона наживаются на вражде российских олигархов

OE4 Roman Abramovich wins court battle with Boris Berezovsky

TE4 Роман Абрамович выиграл суд у Бориса Березовского

OE5 Gorky Park: the jewel in Soviet Moscow's crown shines again

TE5 Парк Горького: бриллиант в короне советской Москвы засиял снова

OE6 Conservative Friends of Russia under fire for launch after Pussy Riot verdict

TE6 «Консервативные друзья России» под огнем критики

OE7 Russia's entry to WTO ends 19 years of negotiations

TE7 После 19 лет переговоров Россия вступает в BTO

OE8 The west's hypocrisy over Pussy Riot is breathtaking

TE8 Лицемерие Запада по поводу Pussy Riot изумляет

OE9 Pussy Riot prove the only professionals in sight

TE9 Pussy Riot - единственные профессионалы в этой истории

OE10 Pussy Riot are a reminder that revolution always begins in culture

TE10 Pussy Riot напоминают о том, что революция всегда начинается в культуре

OE11 Ruling party shows strength amid low turnout in Russian vote

TE11 Правящая партия демонстрирует свою силу на фоне низкой явки на выборы в России

OE12 Happy birthday, Mr. President: Putin turns 60, and Russians pay notice

TE12 С днем рождения, г-н президент: Россия отметила 60-летие Путина

OE13 Rights group says its researcher in Moscow is threatened
Trouw

04.01 .2006

ИноСМИ

05.01.2006

Het Financieele

20.12.2005

Dagblad

ИноСМИ

27.12.2005

The Guardian

08.10 .2012

ИноСМИ

09.10 .2012

The Guardian

04.10 .2012

ИноСМИ

05.10.2012

The Guardian

04.09.2012

ИноСМИ

04.09.2012

The Guardian

31.08 .2012

ИноСМИ

01.09 .2012

The Guardian

26.08.2012

ИноСМИ

27.08.2012

The Guardian

22.08.2012

ИноСМИ

25.08.2012

The Guardian

22.08.2012

ИноСМИ

23.08.2012

The Guardian

21.08.2012

ИноСМИ

22.08.2012

The Guardian

17.08.2012

ИноСМИ

19.08.2012

The Guardian

01.08.2012

ИноСМИ

The New York Times

14.10.2012

ИноСМИ

15.10.2012

The New York Times

17.10.2012

ИноСМИ

18.10.2012

The New York Times 
TE13 Правозащитная организация говорит об угрозах, звучащих в адрес ее московской сотрудницы

OE14 Russians eagerly participate in medical experiments, despite risks

TE14 Россияне охотно участвуют в медицинских экспериментах, несмотря на риски

OE15 Russia moves to broaden definition of high treason

TE15 Россия расширяет понятие государственной измены

OE16 Nation rich in land draws workers from one rich in people

TE16 Страна, богатая землей, привлекает работников из страны, богатой людьми

OE17 Putin's ambitions turn to the Far East

TE17 Амбиции Путина устремлены на Дальний Восток

OE18 Importing Russia’s Top Gun

TE18 Импортируя лучшее российское оружие

OE19 Russia assigns bodyguards to judge ahead of verdict in Pussy Riot trial

TE19 Россия предоставила охрану судье перед вынесением приговора по делу Pussy Riot

OE20 Lugar urges U.S. and Russia to team up to rid Syria of chemical weapons

TE20 Лугар призывает США и Россию совместными усилиями избавить Сирию от химического оружия

OF1 Viha vähemmistöjä kohtaan on Venäjällä syvään juurtunut

TF1 Ксенофобия в России пустила глубокие корни

OF2 Venäjä alkaa palata normaalitilaansa

TF2 Россия начинает возвращаться в свое нормальное состояние

OF3 Molotovin tyttären poika arvostaa vahvaa johtajaa

TF3 "В России рабства нет." Сын дочери Молотова чтит сильного руководителя

OF4 Voittajat ja hävinneet juhlivat yhdessä

TF4 Победители и проигравшие праздную вместе

OF5 Putin johtaa sairasta suurvaltaa

TF5 Путин управляет больным государством

OF6 Historian poliittiset tulkinnat perustettava tutkimukseen

TF6

OF7

TF7 на исторических исследованиях mutta menettely tahditonta. Suomen eduskunnalla itsekritiikin paikka

Финский парламент должен бы быть более
ИноСМИ

05.10 .2012

The New York Times

26.09.2012

ИноСМИ

28.09.2012

The New York Times

22.09 .2012

ИноСМИ

22.09 .2012

The New York Times

11.09.2012

ИноСМИ

12.09.2012

The New York Times

06.09.2012

ИноСМИ

07.09 .2012

The New York Times

15.08.2012

ИноСМИ

18.08.2012

The New York Times

16.08 .2012

ИноСМИ

17.08.2012

The New York Times

07.08.2012

ИноСМИ

08.08.2012

Helsingin Sanomat

09.09 .2006

ИноСМИ

13.09.2006

Ilkka

14.02.2007

ИноСМИ

20.02.2007

Kaleva

08.05.2005

ИноСМИ

12.05.2002

Kaleva

09.05.2005

ИноСМИ

12.05.2002

Pohjalainen

15.05.2006

ИноСМИ

17.05.2006

Turun Sanomat

16.03.2005

ИноСМИ

17.03.2005

Turun Sanomat

07.06 .2006

ИноСМИ

16.06 .2006 самокритичным. Критика, высказанная депутатом Хаутала, имеет право на существование, но место для высказывания подобных мыслей было выбрано не совсем удачно 
OF8 Venäjän supervaltapyrkimys Puolan ja Baltian

Ilkka

17.07.2005

TF8 Стремление России вернуть себе прежние

ИноСМИ

20.07.2005 позиции супердержавы создает проблемы для Польши и стран Балтии

OF9 Miksi Venäjä ei ole uhka

TF9 Почему Россия не представляет угрозы

OF10 Suomi ei ole enää tärkeä Putinille

TF10 Финляндия больше не имеет значения для Путина

OF11 Itsevarmuus palasi Kremliin

TF11 Уверенность вернулась в Кремль

OF12 Kreml järjestelee puoluelaitosta

TF12 Кремль занимается партийным строительством

OF13 Venäjä, Venäjä ja Venäjä

TF13 Россия, Россия и еще раз Россия

OF14 Ruotsi vaikenee Venäjän ulkosuhteista

TF14 Швеция не обсуждает нынешнее состояние внешних связей России

OF15 Tutkija toivoo tarkkuutta Venäjä-politiikkaan

TF15 Эксперт надеется на основательность политики в отношении к России

OF16 Voitonpäivä ja fasismin puolustajat

TF16 День победы и защитники фашизма

OF17 Suomen imu hiipuu hiljalleen

TF17 Финляндия постепенно перестает быть привлекательной

Suomen Kuvalehti

$41 / 2005$

ИноСМИ

18.10.2005

Suomen Kuvalehti

$30 / 2005$

ИноСМИ

29.07.2005

Helsingin Sanomat

03.09.2006

ИноСМИ

05.09 .2006

Helsingin Sanomat

04.09 .2006

ИноСМИ

05.09 .2006

Helsingin Sanomat $\quad 16.09 .2007$

ИноСМИ

01.10 .2007

Turun Sanomat

05.11 .2004

ИноСМИ

05.11 .2004

Ilkka

11.12.2005

ИноСМИ

14.12.2005

Tiedonantaja

29.04.2005

ИноСМИ

02.05 .2005

Keskisuomalainen

08.09 .2006

ИноСМИ

15.09.2006

OF18 Martti Ahtisaaren mielestä Suomella ja Venäjällä on yhteinen ongelma: Päästä eroon Neuvostoliiton

Suomenmaa

19.08.2005 ajasta

TF18 Избавиться от советского синдрома

ИноСМИ

22.08.2005

OF19 Kirje Venäjälle

Viikko-Eteenpäin

16.12 .2004

TF19 Письмо в Россию

ИноСМИ

20.12.2004

OF20 Vamppi-Tarja huvittaa venäläisiä netissä

Ilta-Sanomat

24.07.2010

TF20 Женщина-вамп Тарья позабавила гостей

ИноСМИ

27.07.2010 российского Интернета 